\title{
Antibacterial and Antifungal Property of Actinomycetes Isolates from Soil and Water of Nepal
}

\author{
Binod Lekhak, ${ }^{1}$ Anjana Singh, ${ }^{1}$ Dwij Raj Bhatta ${ }^{1}$ \\ ${ }^{1}$ Central Department of Microbiology, Tribhuvan University, Kathmandu, Nepal.
}

\section{ABSTRACT}

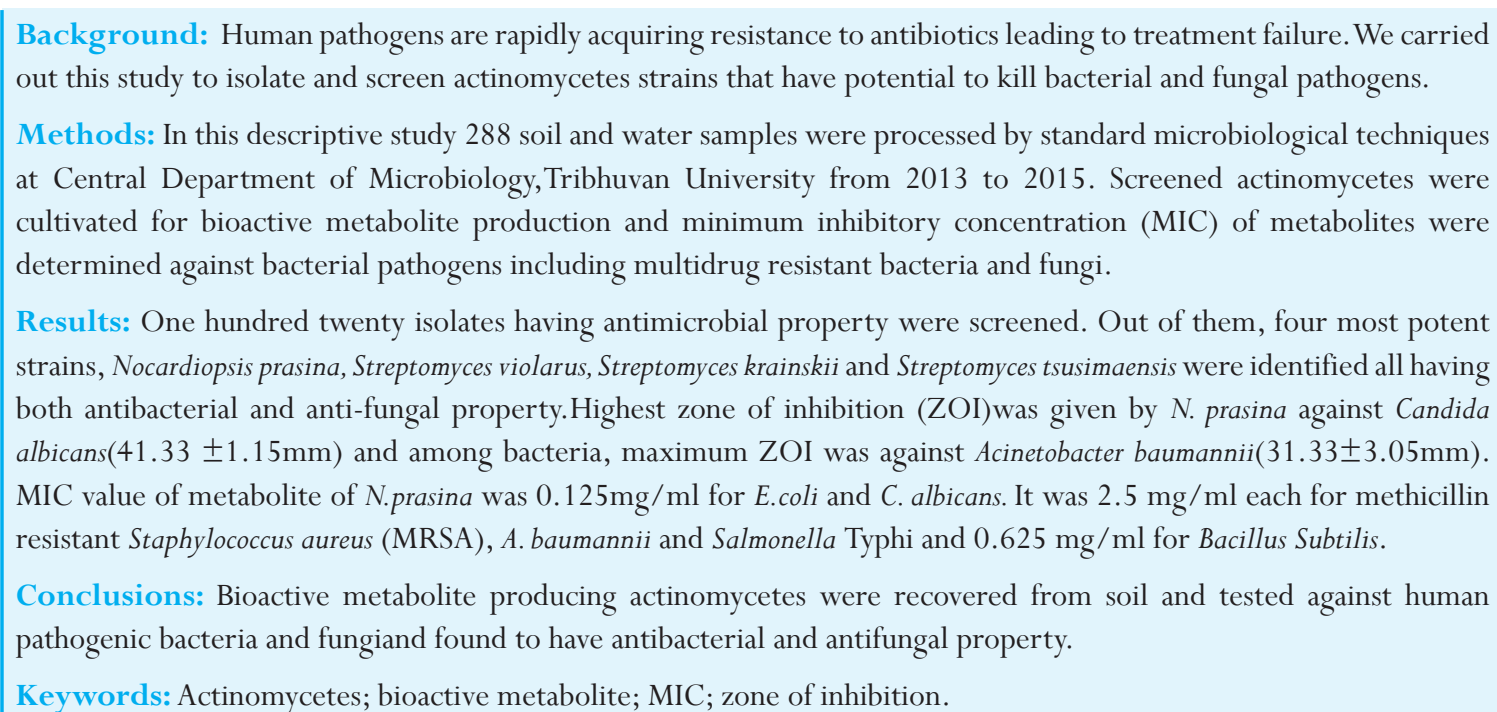

\section{INTRODUCTION}

Antimicrobial resistance creates a great threat for effective prevention and control of several diseases caused by bacteria, fungi, viruses and other parasites. Multidrug resistant Klebsiella pneumoniae, fluoroquinolone resistant E.coli, third generation cephalosporin resistant Neisseria gonorrhoae, methicillin resistant Staphylococcus aureus (MRSA) and Colistin resistant enterobacteriaceae and many other microbes have been reported from different parts of the globe. ${ }^{1}$ Human pathogens such as carbapenem resistant Acinetobacter baumannii, Pseudomonas aeruginosa and enterobacteriaceae have been given top priority. Similarly, vancomycin resistant enterococci, MRSA, fluoroquinolone resistant Salmonella, Campylobacter and Shigella spp. along with many other multidrug resistant pathogens create problem so that new antibiotics should be developed to address resistance problem. ${ }^{2}$ Antibiotics are bioactive secondary metabolites produced by bacteria, fungi and plants. Among diverse microbes actinomycetes are most capable candidates of producing antibiotics. Out of 22,500 biologically active compounds obtained from microbes, $45 \%$ are from actinomycetes, $38 \%$ from fungi and $17 \%$ from other bacteria. ${ }^{3}$ Over 5000 antibiotics have been identified from the culture of Gram +ve, Gram -ve bacteria and fungi. ${ }^{4}$ Among actinomycetes, various Streptomyces spp. account for more than $70 \%$ of total antibiotic production followed by other species. ${ }^{5}$ Actinomycetes are Gram +ve, filamentous bacteria with high guanine+cytosine content of over $55 \%$ in their DNA. ${ }^{6}$ Actinomycetes are natural inhabitant of soil, fresh water, marinewater, lakes and sediments and even found in extreme environment such as Himalayas and hot springs. ${ }^{7}$ Hence, this study was conducted to isolate and screen potent antibiotic producing strains of actinomycetes against bacterial and fungal pathogens.

\section{METHODS}

This study was carried out at Central Department of Microbiology, Tribhuvan University. In this study, 240 soil and 48 water samples were collected from different geographical locations of Nepal and actinomycetes
DOI: http://dx.doi.org/10.3126/ inhrc.v16i2.20298
Correspondence: Dr Binod Lekhak,Central Department of Microbiology, Tribhuvan University, Kathmandu, Nepal. Email: binodlekhak9@gmail.com, Phone:+9779849509243. 
were isolated by spread plate technique on starch casein agar. $^{8}$ Isolates were primarily screened for antimicrobial property against bacterial and fungal pathogens by perpendicular streak method on Mueller Hinton agar. ${ }^{9}$ The strains showing antimicrobial property were cultivated under optimum conditions in starch casein broth at $30^{\circ} \mathrm{C}$ for 7 days at $150 \mathrm{rpm}$ and bioactive metabolites were extracted in ethylacetate. The extracts were subjected to secondary screening against Bacillus subtilis, MRSA, E.coliATCC25922, Acinetobacter baumannii(MDR), Salmonella Typhi(MDR) and Candida albicans by agar well diffusion method. ${ }^{10}$ Minimum inhibitory concentration(MIC) of extracts were determined by tube dilution method. ${ }^{11}$ Strains exhibiting both antibacterial and antifungal activities were characterized phenotypically on the basis of gram straining, sugar utilization test (Glucose, Mannitol, Sucrose, Fructose, Xylose etc.) substrate utilization test such as starch casein and gelatin, tolerance to different temperatures and sodium chloride concentration. ${ }^{12}$ Molecular characterization was carried out by extracting DNA running PCR using universal primer and sequencing. ${ }^{13} \mathrm{All}$ the data generated were entered in excel file and SPSS version 20 and mean, standard deviation, frequency and percentage were calculated.

\section{RESULTS}

A total of 288 soil and water samples from different geographical locations of Nepal were subjected to isolation of actinomycetes. Altogether 120 different actinomycetes showing antimicrobial properties were separated on the basis of pigmentation (Figure 1). Actinomycetes strains producing white and dirty white pigments were most predominant each $17 \%$.

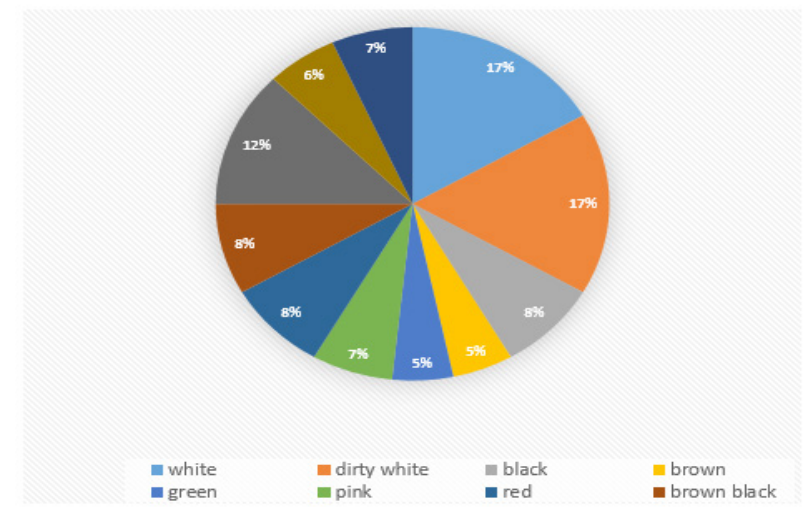

Figure 1: Types of actinomycetes on the basis of pigmentation
Among them 60 isolates were active against only Gram +ve bacteria, 44 isolates against only Gram -ve bacteria, 6 isolates showed activity against both Gram +ve and Gram -ve bacteria while 4 isolates exhibited both antifungal and antibacterial activity. Four most potent isolates were identified as Nocardiopsis prasina $\left(\mathrm{A}_{3}\right)$, Streptomyces violarus $\left(D_{2}\right)$, Streptomyces krainskii $\left(P_{4}\right)$ and Streptomyces tsusimaensis $\left(\mathrm{J}_{1}\right)$ (Table 1 ).

Table 1. Activity of bioactive actinomycetes against bacteria and fungi.

\begin{tabular}{|c|c|c|c|c|c|}
\hline \multirow[b]{2}{*}{ S.N. } & \multirow[b]{2}{*}{$\begin{array}{l}\text { Colony } \\
\text { color }\end{array}$} & \multicolumn{4}{|c|}{ Active against } \\
\hline & & $\begin{array}{r}\text { Gram } \\
+ \text { ve } \\
\text { only }\end{array}$ & $\begin{array}{r}\text { Gram } \\
\text {-ve } \\
\text { only }\end{array}$ & $\begin{array}{r}\text { Both } \\
\text { Gram +ve } \\
\text { and Gram } \\
\text {-ve }\end{array}$ & $\begin{array}{r}\text { Fungi } \\
\text { and } \\
\text { Bacteria }\end{array}$ \\
\hline 1 & White & 8 & 8 & 2 & 2 \\
\hline 2 & $\begin{array}{l}\text { Dirty } \\
\text { White }\end{array}$ & 8 & 8 & 3 & 1 \\
\hline 3 & Black & 3 & 7 & 0 & 0 \\
\hline 4 & Brown & 1 & 5 & 0 & 0 \\
\hline 5 & Green & 4 & 2 & 0 & 0 \\
\hline 6 & Pink & 6 & 2 & 0 & 0 \\
\hline 7 & Red & 4 & 6 & 0 & 0 \\
\hline 8 & $\begin{array}{l}\text { Brown } \\
\text { Black }\end{array}$ & 7 & 3 & 0 & 0 \\
\hline 9 & Grey & 10 & 3 & 1 & 1 \\
\hline 10 & Yellow & 7 & 0 & 0 & 0 \\
\hline 11 & Purple & 2 & 0 & 0 & 0 \\
\hline
\end{tabular}

Antimicrobial activity of bioactive compound extracted in ethyl acetate is shown in Table 2. Out of 4 potent isolates $N$. prasina showed highest antimicrobial activity against Candida albicans (41.33 \pm 1.15$)$, Salmonella Typhi(24.33 \pm 2.08$)$, Acinetobacter baumannii $(31.33 \pm 3.05)$, MRSA $(30.67 \pm 7.02)$ and Bacillus subtilis(24.67 \pm 2.08$)$ while S. krainskii showed highest zone of inhibition against E.coli $(26 \pm 0.00)$.

In MIC evaluation of bioactive compound, Nocardiopsis prasina showed lowest values against all test organisms $0.125 \mathrm{mg} / \mathrm{ml}$ for C. albicans and E.coli, $2.5 \mathrm{mg} / \mathrm{ml}$ for $S$. Typhi, A. baumannii and MRSA. For Bacillus subtilis all isolates gave same value $0.625 \mathrm{mg} / \mathrm{ml}$ (Table 3 ). 
Table 2. Antimicrobial activity of extract against selected pathogens.

Strain

Zone of inhibition (mean \pm S.D.)mm

\begin{tabular}{lrrrrrr} 
& $\begin{array}{r}\text { Bacillus } \\
\text { subtilis }\end{array}$ & MRSA & E.coli ATCC & $\begin{array}{r}\text { Acinetobacter } \\
\text { baumanii }\end{array}$ & $\begin{array}{r}\text { Salmonella } \\
\text { Typhi }\end{array}$ & $\begin{array}{r}\text { Candida } \\
\text { albicans }\end{array}$ \\
\hline A3 & $24.67 \pm 2.08$ & $30.67 \pm 7.02$ & $23.33 \pm 4.93$ & $31.33 \pm 3.05$ & $24.33 \pm 2.08$ & $41.33 \pm 1.15$ \\
\hline D2 & $17.33 \pm 1.15$ & $19.33 \pm 1.52$ & $15.00 \pm 1.00$ & $18.33 \pm 1.15$ & $14.00 \pm 1.00$ & $24.67 \pm 1.52$ \\
\hline PY & $24.33 \pm 0.57$ & $31.33 \pm 3.21$ & $26.00 \pm 0.00$ & $28.00 \pm 2.00$ & $19.00 \pm 1.00$ & $29.33 \pm 0.57$ \\
J1 & $14.33 \pm 2.08$ & $23.33 \pm 2.08$ & $24.67 \pm 0.57$ & $21.67 \pm 1.52$ & $17.33 \pm 0.57$ & $28.67 \pm 1.52$ \\
\hline
\end{tabular}

Table 3.MIC values of bioactive compounds from different strains.

\begin{tabular}{lrrrrrr} 
Strains & \multicolumn{7}{c}{ MIC against(mg/ml) } \\
& B. Subtilis & MRSA & E.coli ATCC25922 & A.baumannii(MDR) & S. Typhi(MDR) & C. albicans \\
\hline $\mathrm{A}_{3}$ & 0.625 & 2.5 & 0.125 & 2.5 & 2.5 & 0.125 \\
$\mathrm{D}_{2}$ & 0.625 & 5 & 2.5 & 5 & 5 & 2.5 \\
$\mathrm{P}_{4}$ & 0.625 & 5 & 2.5 & 2.5 & 2.5 & 2.5 \\
$1\left(\mathrm{~J}_{1}\right)$ & 0.625 & 5 & 5 & 5 & 2.5 & 2.5 \\
\hline
\end{tabular}

\section{DISCUSSION}

In this study, we have isolated and screened bioactive compound producing actinomycetes strains. White and gray colored actinomycetes were predominant and most of them were active against Gram +ve bacteria. This result is similar with Mabrouk and Saleh( 2014) who reported dominance of white and gray actinomycetes with $64.3 \%$ active against Gram +ve bacteria. ${ }^{9}$ Higher susceptibility of Gram +ve bacteria is due to lacking outer lipopolysaccharide which is impermeable to lipophilic compounds. ${ }^{14}$ Results of our study is supported by Vengadesh et al., who found actinomycetes isolate $A_{5}$ was inhibitory to Bacillus subtilis, E.coli, C.albicans and Aspergillus flavus. ${ }^{15}$ Our results are in agreement with Singh et al (2016) who observed high antibacterial activities of three actinomycetes strains against many test bacteria including MRSA, vancomycin resistant enterococci (VRE) and Klebsiella pneumoniae. ${ }^{16}$ Results of this study showed that all four potent actinomycetes were active against bacteria and fungi with $N$. prasinaas best candidate. MIC values of bioactive metabolite ranging from $0.125 \mathrm{mg} / \mathrm{ml}$ to $5 \mathrm{mg} /$ $\mathrm{ml}$. Similar to our findings, MIC value of metabolite of active actinomycetes as $1.25 \mathrm{mg} / \mathrm{ml}$ for MRSA and other many bacteria. Similarly, MIC was $2.5 \mathrm{mg} / \mathrm{ml}$ against VRE, Shigella dysenteriae and Klebsella pneumoniae. ${ }^{17}$ In contrast, Satish and Kokati(2017) reported low MIC value of $1 \mathrm{mg} / \mathrm{ml}$ for MDRSA. ${ }^{18}$ MIC value is affected by many parameters including susceptibility of organisms, type of microorganism, concentration and type of bioactive metabolites, composition of cultural medium, incubation temperature and time. ${ }^{15}$

\section{CONCLUSIONS}

Our study showed that soil and water of Nepal contained diverse actinomycetes strain that can inhibit the growth of some bacteria and Candida albicans. Among screened isolates $N$. prasina was found to be the most effective against test bacteria and fungi. Further studies regarding characterization of bioactive compound is essential.

\section{ACKNOWLEDGEMENTS}

I am grateful to my supervisor Prof Dr Dwij Raj Bhatta and co-supervisor Prof Dr Anjana Singh for their valuable suggestion to develop concept and designing research and also guiding me during my laboratory work. Equally. I would like to acknowledge Prof $\mathrm{Dr}$ Giorgio Palu, Director, Department of Molecular Medicine, Padova University, Italy for providing laboratory facility to study antimicrobial activities of actinomycetes and sequencing actinomycetes strains.

\section{REFERENCES}

1. WHO. Antimicrobial Resistance. Fact sheet updated 2017. [Full Text]

2. WHO.WHO Publishes list of bacteria for which new antibiotics are urgently needed.News release, .Media center. 2017.[Full Text]

3. Berdy J. Bioactive microbial metabolites. J Antibiot. 2005;58(1):1. [Google Scholar]

4. Hayakawa Y, Shirasaki S, Shiba S, Kawasaki T, Matsuo Y, Adachi K, Shizuri Y. Piericidins C 7 and C 8, New Cytotoxic Antibiotics Produced by a Marine Streptomyces sp. J Antibiot. 2007;60(3):196.[Link] 
5. Lam KS. Discovery of novel metabolites from marine actinomycetes. Curr Opin Microbiol. 2006 Jun 1;9(3):245-51. Google Scholar]

6. Ventura M, Canchaya C, Tauch A, Chandra G, Fitzgerald GF, Chater KF, van Sinderen D. Genomics of Actinobacteria: tracing the evolutionary history of an ancient phylum. Microbiol Mol Biol Rev. 2007 Sep 1;71(3):495-548. [Google Scholar]

7. Gurung TD, Sherpa C, Agrawal VP, Lekhak B. Isolation and characterization of antibacterial actinomycetes from soil samples of Kalapatthar, Mount Everest Region. Nepal Journal of Science and Technology. 2009;10:173-82.[DOI]

8. Küster E, Williams ST. Selection of media for isolation of streptomycetes. Nature. 1964 May;202(4935):928. [Google Scholar]

9. Mabrouk MI, Saleh NM. Molecular identification and characterization of antimicrobial active actinomycetes strains from some Egyptian soils.American-Eurasian J Agric Environ Sci.2014;14(10):954-963

10. Boyanova L, Gergova G, Nikolov R, Derejian S, Lazarova E, Katsarov N, Mitov I, Krastev Z. Activity of Bulgarian propolis against 94 Helicobacter pylori strains in vitro by agar-well diffusion, agar dilution and disc diffusion methods. J Med Microbiol. 2005 May 1;54(5):481-3. [Google Scholar]

11. Jorgensen JH, Turnidge JD. Susceptibility test methods: dilution and disk diffusion methods. InManual of Clinical Microbiology, Eleventh Edition 2015 Jun 1 (pp. 12531273). American Society of Microbiology. [Google Scholar]
12. Bergey DH, Holt JG. Actinomycetales. In Bergey's manual of determinative bacteriology.2000.9th edition,Lippincott Williams and Wilkins, Philadelphia.

13. Lane DJ. 16S/23S rRNA sequencing. Nucleic acid techniques in bacterial systematics.. 1991. [Google Scholar]

14. Scherrer R, Gerhardt P. Molecular sieving by the Bacillus megaterium cell wall and protoplast. J Bacteriol. $1971 \mathrm{Sep}$ 1;107(3):718-35.[Link]

15. Vangadeesh S, Sundarmurthi C,Karthic K, SelvarajuK. Production and evaluation of antibiotics from soil isolated actinomycetes. International Journal of Institutional Pharmacy and Life Sciences.2011;1(1):138-152

16. Chaudhary HS, Yadav J, Shrivastava AR, Singh S, Singh AK, Gopalan N. Antibacterial activity of actinomycetes isolated from different soil samples of Sheopur (A city of central India). J Adv Pharm Technol Res. 2013:4(2):118-123[Full Text]

17. Singh V, Haque S, Singh H, Verma J, Vibha K, Singh R, Javed A, Tripathi CKM. Isolation,screening and identification of novel isolates of actinomycetes from India. Front Microbiol. 2016;7:1921.[Full Text]

18. Kumar SR S, Rao KV. In-vitro antimicrobial activity of marine actinobacteria against multidrug resistance Staphylococcus aureus. Asian Pac JTrop Biomed. 2012 Oct 1;2(10):787-92.[Science Direct] 